\title{
Haydena Whita - živé písanie o dejinách
}

\author{
JURAJ ŠUCH*
}

Hayden White - Living Writing on History

\begin{abstract}
The author of the article points out the main shifts in Hayden White's reflection on narrative history writing. These shifts are related to his emphasis on the role of tropes and figures in dealing with the problem of narrative representation in the past. In the author's view, White's works challenge a traditional understanding of history, while stressing terminal validity and plurality in narrative representations of historical reality. He also points out that Czech and Slovak scholars used some aspects of Hayden White's understanding of history for explaining different representations of history.
\end{abstract}

Keywords: Hayden White; history; historical narrative; figuration; practical past

DOI: $10.14712 / 23363525.2019 .9$

V minulom roku uplynulo 90 rokov od narodenia Haydena Whita, amerického bádatela, ktorého práce pútali pozornost' vo viacerých humanitných disciplínach predovšetkým od druhej polovice 80 . rokov minulého storočia. $S$ jeho menom sa spája okrem iného vydanie knihy Metahistóra [1973] a súbory statí v publikáciách Trópy diskurzu [1978], Obsah formy [1987], Figurálny realizmus [1999], Praktická minulost' [2014]. Tieto publikácie sa stali predmetom diskusií nielen medzi historikmi, ale aj literárnymi teoretikmi a filozofmi.

Životná dráha Whita bola poznačené skúsenostou zo života v robotníckej rodine v Detroite, ako aj službou vo vojenskom námorníctve, ktoré mu umožnilo štúdium histórie na Wayne State University. Na univerzite sa zúčastňoval charizmatických prednášok Williama J. Bossenbrooka, ktoré poukazovali na dejinotvornú úlohu historikov. Whitova pozitívna skúsenost' s akademickým prostredím a najmä vplyv Bossenbrookových prednášok zo stredovekých dejín ho viedli $\mathrm{k}$ doktorandskému štúdiu venovanému problematike dejín katolíckej cirkvi a pápežskej schizmy v roku 1130 na Univerzite v Michigane. Počas tohto štúdia White využil dvojročný pobyt $\mathrm{v}$ Ríme nielen na prácu $\mathrm{v}$ archívoch, ale zároveň sa detailnejšie zoznámil s talianskymi prácami reflektujúcimi problematiku histórie v rokoch 1954-1955. ${ }^{1}$ Od polovice 50. rokov White pôsobil dva roky na Katedre histórie v Detroite a nasledujúcich desat rokov (do roku 1968) bol asistentom na Univerzite v Rochesteri.

$\mathrm{Na}$ jednej strane Whitove historické práce zo stredovekých dejín dokumentovali použitie teórie Maxa Webera pri skúmaní problematiky vývoja v cirkvi. Na druhej strane texty o histórii zdôrazňovali potrebu zaujat určitý hodnotový postoj pri spracovávaní historických poznatkov. Whitov postupne silnejúci záujem o problematiku charakteru histórie

" Doc. PhDr. Juraj Šuch, Ph.D., Katedra filozofie, Filosofická fakulta, Univerzita Mateja Béla, Tajovského 40, 97401 Banská Bystrica. E-mail: Juraj Šuch@umb.sk.

1 White prekladá do anglického jazyka knihu Carla Antoniho Od histórie k sociológii (1959), v ktorej predhovor napísal Benedetto Croce. White v úvode tejto publikácie ocenil podnetnost Croceho humanistického historizmu, pričom sa bližšie jeho názorom venoval v spomienkovej stati Pretrvávajúca dôležitost Croceho idey histórie [1963]. 
sa spájal s presvedčením, že historik nie je pasívny sprostredkovatel' poznatkov z výskumu, ale intelektuálny dejinný činitel', ktorý svojou predstavou minulosti participuje na formovaní budúcnosti. Zároveň so zdôrazňovaním možnosti historika vplývat na podobu minulosti a tým ovplyvňovat budúcnost', White pripomínal historikovu intelektuálnu slobodu a zodpovednost'. Preto nie je prekvapujúce, že ho oslovili práce Benedetta Croceho a existencialistov. ${ }^{2}$ Dokladom Whitovho presvedčenia o úzkej súvislosti medzi vývojom vo vede a slobodou bola jeho spolupráca s Willsonom Coatsom na dvojzväzkových dejinách o intelektuálnej histórii Objav liberálneho humanizmu [1966] a Skúška liberálneho humanizmu [1970]. V nich sa uvedená predstava liberálneho humanizmu viazala na proces neustále sa meniacich životných podmienok ludí. Na základe tohto chápania situácie človeka predstavoval ludský život „neustále preskúmavanie a prehodnocovanie, v každom akte bola pokusom poznat' seba samého v danom momente histórie, pričom človek odhaluje nový aspekt svojej esenciálnej kreativity“ [Coates - White - Schapiro 1966: 5]. Samotný liberálny humanizmus, autori chápali skôr ako kritickú tradíciu alebo dispozíciu, ktorú ilustrovala postava rebela. Pôsobenie rebela malo byt’ „zasvätené zmenšovaniu násilia vo svete a zvyšovaniu pragmatickej slobody aj na úkor dokonalej spravodlivosti“ [Coates White 1970: 466].

Whitovo „existenciálne“ ladené kladenie otázok o úlohe histórie a jej zmysle pre spoločnost’ sa objavuje v jeho známej stati Bremeno histórie [1966]. Samotnú krízu vo vnímaní histórie pripisoval metodologickému naivizmu, podla ktorého bola história „kombinací spoločenských věd ze sklonku 19. století a umění z poloviny 19. stoleti“ [White 2010: 58]. Východisko z krízy histórie videl White v hlbšom uvedomovaní si konštrukčného charakteru vedy a umenia, ktoré malo viest' cez používanie rôznych metafor k tvorbe impresionistickej, expresionistickej alebo existenciálnej historiografie. Ohlasy na túto prácu podnietili Whita k práci na jeho najznámejšej knihe Metahistória, ktorou sa podla Ewy Domańskej končí prvá etapa v jeho bádatel’ských záujmoch označovaná ako „špekulatívno-idealistická“ a začína „naračno-trópická“ [Domańska 2009: 4-5]. V tomto období White pôsobil na Kalifornskej univerzite. Na rozdiel od Whitových predchádzajúcich prác Metahistória vzbudila krátko po vydaní značný ohlas a stala sa symbolom tzv. lingvistického alebo naratívneho obratu v teórii histórie. $\mathrm{V}$ spojitosti s ňou medzi najdiskutovanejšie problémy patrilo Whitove chápanie tvorby a štruktúry historickej narácie. V narácii sa zrkadlila historikova volba jedného zo štvorice povrchových typov konštrukcie zápletky/sujetu (romance, tragédie, komédie, irónie), argumentácie (formistickej, mechanistickej, organistickej, kontextuálnej), ktoré implikovali určitý typ ideologickej pozície (kontextuálnej, anarchistickej, radikálnej, liberálnej) [White 2011: 21-29]. Formovanie historikovej predstavy o určitých udalostiach bolo podla Whita viazané na jeho hlbinnú úroveň vedomia, ktorá mala byt’ spojená s jedným zo štyroch trópov (metaforou, metonymiou, synekdochou a iróniou) [White 2011: 52-61]. ${ }^{3}$ Výber povrchových typov Whitovho modelu mohol

2 Podla Hermana Paula predovšetkým Whitov existencialistický postoj je klúčový pre pochopenie jeho náhladu na celý rad problémov spojených s písaním o dejinách [Paul 2011]. Domnievame sa, že Whitova inklinácia k prácam existencialistov (najmä Jeana-Paula Sartra a Alberta Camusa) mohla súvisiet’ s reflektovaným pragmatickým postojom intelektuála, ktorý využíval reflexiu na hladanie zodpovedných postojov a následného konania.

3 Paradoxne tento štrukturalistický a „eklektický“ model štvoritej tetrády bol v určitom protiklade k Whitovmu humanistickému historizmu, ktorý zdôrazňoval prirodzenost' „neschematizujúcej“ tvorby historikov [Kellner 1980]. 
byt' aplikovatelný na niektoré aspekty naratívnych zobrazení minulosti, pričom do určitej umožňoval vysvetlenie vzniku vzájomne odlišujúcich sa predstáv o dejinnom vývoji. ${ }^{4}$ Samotná aplikácia modelu v Metahistórii a prípadné detailnejšie domýšlanie na príkladoch vybraných filozofov a historikov z 19. storočia sa stretlo s vážnymi pochybnostami. ${ }^{5}$ $\mathrm{V}$ porovnaní s pokusmi o použitie tropologického modelu bolo pre odbornú komunitu zaujímavejšie Whitovo vyrovnávanie sa s problémom relativity vztahu medzi minulostou a historikmi konštruovanými naráciami. White redukoval relevantnost’ „priameho“ determinovania významov samotnými faktami a v procese historikovho konštruovania narácie otvoril priestor nielen pre tvorivost̉ historika, ale tiež pre koncipovanie alternatívnych zobrazení minulosti. Zároveň s touto redukciou nastolil problém formulovania kritéria vierohodnosti historických narácií a určovania klúčového determinanta pre ich akceptáciu v odbornej komunite.

V prácach zo 70. rokov minulého storočia sa neobjavilo jednoznačné riešenie tohto problému. V súbore statí s názvom Trópy diskurzu prevažovalo Whitovo konkrétne skúmanie procesu zvýznamňovania dát $\mathrm{v}$ historických naráciách $\mathrm{v}$ spojitosti s ich literárnou formou. Predpokladom rôzneho zvýznamňovania udalostí prostredníctvom prirodzeného jazyka bola $\mathrm{z}$ jeho pohladu ich „bezforemnost“; svoju tragickú alebo romantickú formu nadobúdavali až z určitého pohladu historika $\mathrm{v}$ jeho historickom príbehu [White 2010: 110]. Čitatel' v úvodných statiach Trópov diskurzu (napr. Historický text ako literárny artefakt, Fikcia faktickej reprezentácie, Historicizmus, história a figuratívna obrazotvornost') sa stretáva s presvedčivými príkladmi, ktoré ilustrujú potrebu historikovho vhodného používania figuratívnych výrazov. Tieto výrazy podla neho recipientovi umožňujú pochopit’ množstvo určitým spôsobom usporiadaných dát a tým aj „neznámy“ kontext diania v minulosti. Samotné historické texty tak považoval „za verbální artefakty, jejichž obsah je stejnou měrou plodem imaginace, jako je objeveným faktem a jejich forma má blíže $\mathrm{k}$ literatuře než $\mathrm{k}$ vědě“ [White 2010: 106]. Zdranením úlohy recepcie pri prijímaní historických narácií White prirodzene oslabil vnímanie vývoja histórie ako autonómnej vedy.

Problematike naratívneho zobrazenia historickej reality sa White podrobnejšie venoval v statiach z 80. a 90 rokov minulého storočia, ktoré boli neskôr publikované pod názvom Obsah formy [1987] a Figurálny realizmus [1999]. Ewa Domańska tieto Whitove práce spájala so „zobrazovacou alebo diskurzívnou fázou“v jeho názorovom vývoji [Domańska 2007: 5]. V tomto období až do roku 1996 pôsobil ako profesor študijného programu Historického vedomia na Kalifornskej Univerzite v Santa Cruz. Podobne ako v predchádzajúcich dielach aj v týchto statiach upozorňoval na význam figuratívnych výrazov a naratívnej formy pri historikovom konštruovaní narácií, pričom významnejšiu úlohu začal pripisovat ideológiám. Tento posun výstižne ilustrovalo jeho tvrdenie, že moderné ideológie „udelujú význam histórii, čo spôsobuje, že jej evidentný zmätok sa stáva napokon zrozumitel'ným pre rozum, pochopenie alebo estetickú senzitivitu [...] v rozsahu, v akom to uskutočňujú, tieto ideológie zbavujú históriu istého druhu bezvýznamnosti, a tak samotné

4 Je dost prekvapujúce, že možnosti aplikácie Whitovho modelu štvoritej tetrády preskúmal Donald Ostrovsky v stati Metateoretická analýza: Hayden White a štyri narácie z „ruskej“ histórie až v roku 1990. Na limity tohto modelu poukázal aj Kevin Platt v stati Historia a despotizmus, alebo Hayden White vs. Ivan Hrozný a Peter Velký [1999].

5 Bližšie k recepcii Metahistórie [Šuch 2010: 54-69]. 
môžu podnecovat žijúce ludské bytosti a ich deti k utváraniu odlišného spôsobu života, čo znamená, určovat' ich životom význam, za ktorý oni budú plne zodpovedni' [White 1987: 72]. Ak Whitove úvahy nad rôznymi aspektmi formotvorných činitelov naratívnej podoby minulosti boli spočiatku vnímané ako „len zvlášne“ teoretické úvahy, tak koncom 80. rokov minulého storočia vzbudzovali kritické reakcie. ${ }^{6}$

Pre Whitove konštruktivistické chápanie významu literárnej dimenzie naratívneho približovania udalostí bol výzvou osobitý (modernistický) typ udalostí, akým bol napr. holokaust. Pri zamýšlaní sa nad výberom vhodného spôsobu jeho zobrazovania zdôrazňoval nevyhnutnost' historikovho používania figuratívnych výrazov a tým aj prítomnost' určitej estetizácie minulosti v sprostredkujúcich historických naráciách. White navrhol autorom hladat' „prijatelný “ spôsob jazykového spodobenia modernistických udalostí a zvolit si modernistický štýl, tzv. intranzitívne písanie, ktoré malo spodobovat predmet v strednom rode (middle voice) [White 2009: 165-169].

V poslednej publikácii s názvom Praktická minulost' [2014] Whitove úvahy nadväzovali na Michaela Oakshotta a jeho rozlišovanie medzi historickou minulostou a praktickou minulostou [White 2014: 8-9]. Historická minulost' predstavovala pre Whita vysoko selektívnu formu, ktorá sa výrazne začala rozvíjat’ s formovaním histórie ako „nezaujatej“ a hodnotovo neutrálnej vedeckej disciplíny od 19. storočia. Na rozdiel od tohto (ideálneho) typu bola praktická minulost’ viazaná na hodnoty, ktoré napomáhali riešit nielen každodenné rozhodovanie, ale aj krízové situácie v živote spoločnosti [White 2014: 15]. Dôležitým médiom praktickej histórie bol pre Whita moderný román, ktorý so sebou vždy prinášal východiská určitej špekulatívnej filozofie dejín. Tento fakt podla neho znamená pretrvávajúcu aktuálnost' filozofie dejín aj pre postmodernú spoločnost'. Podobne ako pri iných prácach, aj tento krátky súbor statí sprevádzali kritické i oceňujúce reakcie. ${ }^{7}$

Whitovými prácami sa vinie skúmanie spôsobov spracovávania faktov do ucelenejších naratívnych celkov. V kontraste s tradičnou predstavou faktov (dát), z ktorých takmer „jednoznačne“ historik generuje jednu (správnu) podobu minulosti, White priorizoval kritické nahliadanie na proces vytvárania naratívneho celku. V tomto procese poukazoval na konštrukčný (figuratívny) spôsob jazykového priblíženia minulosti, ktorý nemohol byt’ považovaný za model korešpondujúci s historickou realitou. Používanie bežného jazyka a tým aj používanie figuratívnych výrazov v historických textoch viedlo Whita k zdôrazneniu významu literárnej dimenzie historických narácií. Možnost’ rôzneho naratívneho priblíženia diania zvýraznila kreatívnu úloha historikovej predstavivosti a vplyv determinantov participujúcich na konštruovaní obrazu minulosti. Vzhladom na meniace sa dejinné vízie spoločnosti a vypracovávanie odlišných predstáv o historickej realite v komunite historikov White akceptoval neustálu prítomnosṫ vzájomne rozdielnych naratívnych

6 Azda s najostrejšou kritikou Whita vystúpil Carlo Ginsburg, ktorý dával Whitove názory chápal v spojitosti nielen s ideami Croceho, ale aj s Gentileho extrémnym subjektivizmom (implikujúcim myšlienku, že historiografia vytvára svoj vlastný predmet - históriu). Podla neho bol neudržatelný Whitov predpoklad, že relativizmus a skepticizmus môže poskytnút epistemologické a morálne základy pre toleranciu , kedžže „morálne a teoretické rozdiely nie sú ním v podstate viazané na pravdu, a preto nie je čo tolerovat“ [Ginsburg 1992: 93-94]. Ginsburg zostal s týmto kritickým náhladom na Whitove práce osamotený.

7 Príkladom kritického postoja k Whitovej knihe Praktická minulost' je stat' Chrisa Lorenza Tango na tri. História medzi historickou a praktickou minulostou [Lorenz 2014]. Na rozdiel od neho Alun Munslow zaujal v recenzii na Praktickú minulost' podstatne pozitívnejší postoj [2015]. 
priblížení minulosti. Vzájomnú koexistenciu viacerých podôb minulosti vnímal ako výzvu na ich kritické skúmanie. Pre mnohých teoretikov v 80. a 90. rokoch minulého storočia Whitove relativistické chápanie historických narácií, ktoré kládlo dôraz na význam jazyka a zdôvodňovalo ich pluralitu, prirodzene korešpondovalo s ideami postmoderny. Whitove práce sa tak pre jej stúpencov ako aj kritikov stávali alternatívnou teóriou voči tradičnému chápaniu histórie. Túto skutočnost’ vystihuje názov doslovu k Metahistórii od Petra Čorneje: „White nezměnil dějiny, ale pohled na ně“ [Čornej 2011: 575].

I ked' Whitove esejistické práce problematizovali tradičné chápanie histórie, tak nepodávali systematicky precizované „konkurenčné“ chápanie. White reagoval na diskusie humanitných vedcov, pričom neustále „prepracovával“ (upravoval) svoje chápanie histórie. Zároveň sa s tým čoraz viac znejasňovala jeho názorová pozícia v konštruktivistickom názorovom spektre. Pre orientáciu v intelektuálnom vývoji a zdrojoch Whitových názorových posunov sú vel'mi nápomocné práce najvplyvnejších znalcov Whitových textov, ktorými sú Herman Paul a Ewa Domańska. Pre niektorých čitatelov môžu byt’ ich interpretácie až vel'mi ústretové, alebo naopak príliš kritické.

Začiatkom 90. rokoch minulého storočia mohli byt’ českí a slovenskí čitatelia informovaní o Whitových dielach prostredníctvom kritických reakcií k nim (napr. u Jaroslava Marka). Prvým preloženým textom bola Whitova stat Historicizmus, historie a figuratívna obraznost v Reflexii v roku 1996, v ktorej sa zároveň publikovala aj ostrá kritika Metahistorie od Herty Nagl-Docekalovej. Na Slovensku bola prvým prekladom Whitova práca Fikcia faktickej reprezentácie, publikovaná v roku 1998 v Slovenskej literatúre. Podstatne väčší záujem o Whitove myšlienky sa prejavil začiatkom 21. storočia, kedy sa čoraz viac bádatelov malo možnost’ zoznámit’ s Whitovými prácami. Tomáš Horváth zdôvodňoval svoju kritiku „jednej pravdivej“ literárnej histórie v knihe Rétorika histórie [2002] s odvolávaním sa na Whitove tropologické chápanie histórie. Podobne sa Milan Repa vo svojej knihe Poetika českého dějepisectví [2006] prihlásil k podnetnosti Whitovej tropológie pre svoju analýzu predstavovania dejín v prácach českých historikov (F. Palackého, J. Pekaře, J. Šustu, O. Odložilíka). Na niektoré Whitove myšlienky sa odvolával vo svojej knihe Dějiny a vyprávění [2011] Kamil Činátl. Podobne ako kniha Milana Řepy, tak aj kniha Kamila Činátla podnietila polemickú reakciu v jej recenzii. Whitovými myšlienkami bola inšpirovaná neskôr aj stat Martina Vašša Možné aplikácie naratívneho konštruktivismu Haydena Whita pri historiografickej analýze vybraných diel [Vašš 2015: 193-208]. Na problém Whitovej koncepcie pri „teste holokaustom“ upozornil Lubomír Doležel [2008].

Whitove chápanie histórie bolo komplexnejšie priblížené Karlom Šimom v spojitosti s tzv. lingvistickým obratom v histórii v zborníku Lucie Storchovej a Jana Horského Paralely, průsečíky, mimobežky [2009]. Podobne ako Karel Šíma pripustil aj Jan Horský opodstatnenost' Whitovho kritického postoja k nevyhnutne ideologickému nasycovaniu historických textov vo svoje knihe Dějepisectví mezi vědou a vyprávěním [2009]. Vzhladom na silný kultúrny vplyv nemeckej historickej tradície na našom území, ktorá Whitove práce vníma skôr ako zvláštnost', aj medzi českými a slovenskými historikmi je možné očakávat', že jeho relativistické chápanie histórie bude prijímané skôr polemicky. Významným prínosom pre zaujatie erudovaného postoja humanitných vedcov $\mathrm{k}$ Whitovým myšlienkam bolo vydanie prekladov publikácií Tropika diskursu [2010] a Metahistorie [2011]. K vybraným aspektom Whitových prác bol na Slovensku vydaný zborník prác s názvom Mnohotvárnost' Haydena Whita [2013]. 
Napriek tomu, že White nikdy neprednášal v Čechách a na Slovensku (narozdiel od Pol'ska a Mad’arska), tak jeho práce vzbudzovali pozornost' u viacerých bádatelov. Domnievame sa, že napriek jeho skonu v marci minulého roka bude pretrvávat aktuálnost’ jeho prác. Potreba prispôsobenia sa novým historickým podmienkam bude vyžadovat nové pohlady a spracovanie značného množstva faktografického materiálu. Podobne ako White budeme hladat' spôsoby vhodného približovania diania minulosti pre súčasníkov, ktoré by zohladňovali aj ich etické aspekty. Pri vyrovnávaní sa s trvalo prebiehajúcim procesom „prepisovania histórie“ sa môžeme vyhnút „slepý uličkám“ a pracovat’ na úprave ciest, ktorými už prešiel Hayden White.

\section{Literatúra}

Coates, Willson - White, Hayden - Schapiro, Jacob S. [1966]. The Emergence of Liberal Humanism. Intellectual History of Western Europe I. New York: McGrew-Hill.

Coates, Willson - White, Hayden [1970]. The Ordeal of Liberal Humanism. Intellectual History of Western Europe II. New York: McGrew-Hill.

Činátl, Kamil [2011]. Dějiny a vyprávění. Praha: Argo.

Čornej, Petr [2011]. White nezměnil dějiny, ale pohled na ně. In. White, Hayden. Metahistorie. Brno: Host, s. 575-600.

Doležel, Lubomír [2008]. Fikce a historie v období postmoderny. Praha: Academia.

Domańska, Ewa [2009]. Intelektuálna biografia Haydena Whita. Úvod do problematiky. Forum Historiae 3 (2). Dostupné z: http://www.forumhistoriae.sk/FH2_2009/texty_2_2009/domanska.pdfs.1-20.

Ginsburg, Carlo [1992]. Narrativity and Historical Representation. In. Friedlander, Saul (ed.). Probing the Limits of Representation. Cambridge: Harvard University Press, s. 82-96.

Horský, Jan [2009]. Dějepisectví mezi vědou a vyprávěním. Praha: Argo.

Horváth, Tomás [2002]. Rétorika histórie. Bratislava: Veda.

Kellner, Hans [1980]. Bedrock of Order: Hayden White. History and Theory 16 (4): 1-29.

Lorenz, Chris [2014]. It takes three to tango. History between the „historical“ and the "practical“ past. Storia della Storiografia 65 (1): 29-46.

Munslow, Alun [2015]. Review. Rethinking history 19 (4): 694-702.

Nagl-Docekal, Herta [1996]. Lze založit filosofii dějin tropologicky? Reflexe 16: 7(1-12).

Ostrowski, Donald [1990]. A Metatheoretical Analysis: Hayden White and Four Narratives of „Russian“ History. Clio 19 (3): 215-235.

Paul, Hermann [2011]. Hayden White: The Historical Imagination. Cambridge: Polity Press.

Platt, Kevin [1999]. History and Despotism, or Hayden White vs Ivan the Terrible and Peter the Great. Rethinking history 3 (3): 247-269.

Řepa, Milan [2006] Poetika českého dějepisectví. Brno: Host.

Šíma, Karel [2009]. Velké vyprávění o lingvistickém obratu v teorii dějin a malý př́běh české historiografie. In. Storchová, Lucie - Horský, Jan. Paralely, průsečíky, mimobežky. Praha: Albis International, s. 67-94.

Šuch, Juraj [2010]. Naratívny konštruktivizmus Haydena Whita a Franka Ankersmita. Ostrava: Ostravská univerzita.

Vašš, Martin [2015]. Možné aplikácie naratívneho konštruktivismu Haydena Whita pri historiografickej analýze vybraných diel. Historica Olomucensia 48: 193-208.

White, Hayden [1987]. The Politics of Historical Interpretation: Discipline and De-Sublimation. In. The Content of the Form. Baltimore: The John Hopkins University Press, s. 58-82.

White, Hayden [1999]. Figural Realism: Studies in the Mimesis Effect. Baltimore: The Johns Hopkins University Press.

White, Hayden [2009]: Historický sujet a problém pravdy v historickej reprezentácii. In. Kapitoly zo súčasnej filozofie dejín. Bratislava: Chronos, s. 54-170.

White, Hayden [2010]. Tropika diskursu: Kulturně kritické eseje. Praha: Karolinum. 
White, Hayden [2011]. Metahistorie. Brno: Host.

White, Hayden [2014]. The Practical Past. Evanston: Northwestern University Press.

Zeleňák, Eugen (ed.) [2013]. Mnohotvárnost' Haydena Whita. Bratislava: Chronos.

Juraj Šuch $\left({ }^{*} 1969\right)$ absolvoval vysokoškolské štúdium na Filozofickej fakulte Univerzity Pavla Jozefa v Prešove. Od roku 1997 pôsobí na Filozofickej fakulte Univerzity Mateja Béla v Banskej Bystrici. Vo svojom výskume sa zameriava na problémy filozofie dejín, predovšetkým na naratívnu filozofiu histórie Haydena Whita a Franka Ankersmita. 